\title{
Climate change communication programs - a case study for local government managers in Thuan An district, Binh Duong province
}

- Le Ngoc Tuan

University of Science - Vietnam National University Ho Chi Minh City

- Dien Thi Thu Trang

Institute of Meteorology Hydrology Oceanology and Environment

(Received 07 March 2016, accepted 16 May 2016)

\section{ABSTRACT}

95\% of the causes of climate change (CC), according to the Intergovernmental Panel on Climate Change (IPCC), are rooted from human activities. Raising community awareness is, thus, the primary solution to the issue. This research aims to develop communication programs to raise public awareness of $C C$, a case study in Thuan An District. The context, object properties, information gaps, and communication demand, etc. have been surveyed and documented.
Thereby, the CC communication programs were proposed, including: objectives, messages, media, and compatible communication activities, etc. The communication materials (manuals, posters, training books, etc.) were also compiled accordingly. This model can be expanded in other areas, contributing to improvement of managers' awareness and management capacity, and then being more proactive in coping to the current situation of CC in the province.

Keywords: Climate change (CC), Communication, Coping to climate change.

\section{INTRODUCTION}

Climate change (CC) is one of the greatest challenges which human beings must encounter in $21^{\text {st }}$ century and Viet Nam is one of five countries which has been most severely affected by CC [1]. According to IPCC [2], 95\% of the main causes of $\mathrm{CC}$ are resulted from human activities. Nowadays, positively change in awareness of $\mathrm{CC}$ has become one of key issues in the mission of response to CC. In Viet Nam, managers are responsible for conducting, supervising, and controling activities related to $\mathrm{CC}$; integrating $\mathrm{CC}$ response activities into development programs and plans; establishing and supporting $\mathrm{CC}$ communication activities in the local, ect. [3]. Therefore, improving awareness of CC for managers is absolutely necessary [3-10]. However, researching and establishing CC communication programs in general and for managers in particular are not yet systematic and still limited.

Thuan An district (Binh Duong province) has been negatively affected by CC. According to the point of view, objectives, and orientations of National Target Program to Respond to CC [8], 
one of the objectives of The action plan to repond to $C C$ in Binh Duong province in general and Thuan An district in particular is $100 \%$ of officials and civil servants (named as managers) to be trained to improve their capacity of reponding to $\mathrm{CC}$ and preventing natural disasters
[9-10]. Accordingly, this research, piloted in Thuan An district (Binh Duong province), aims to establish $\mathrm{CC}$ communication programs for managers, contributing to improving awareness, increasing concern and capacity to respond to CC.

\section{METHODS}

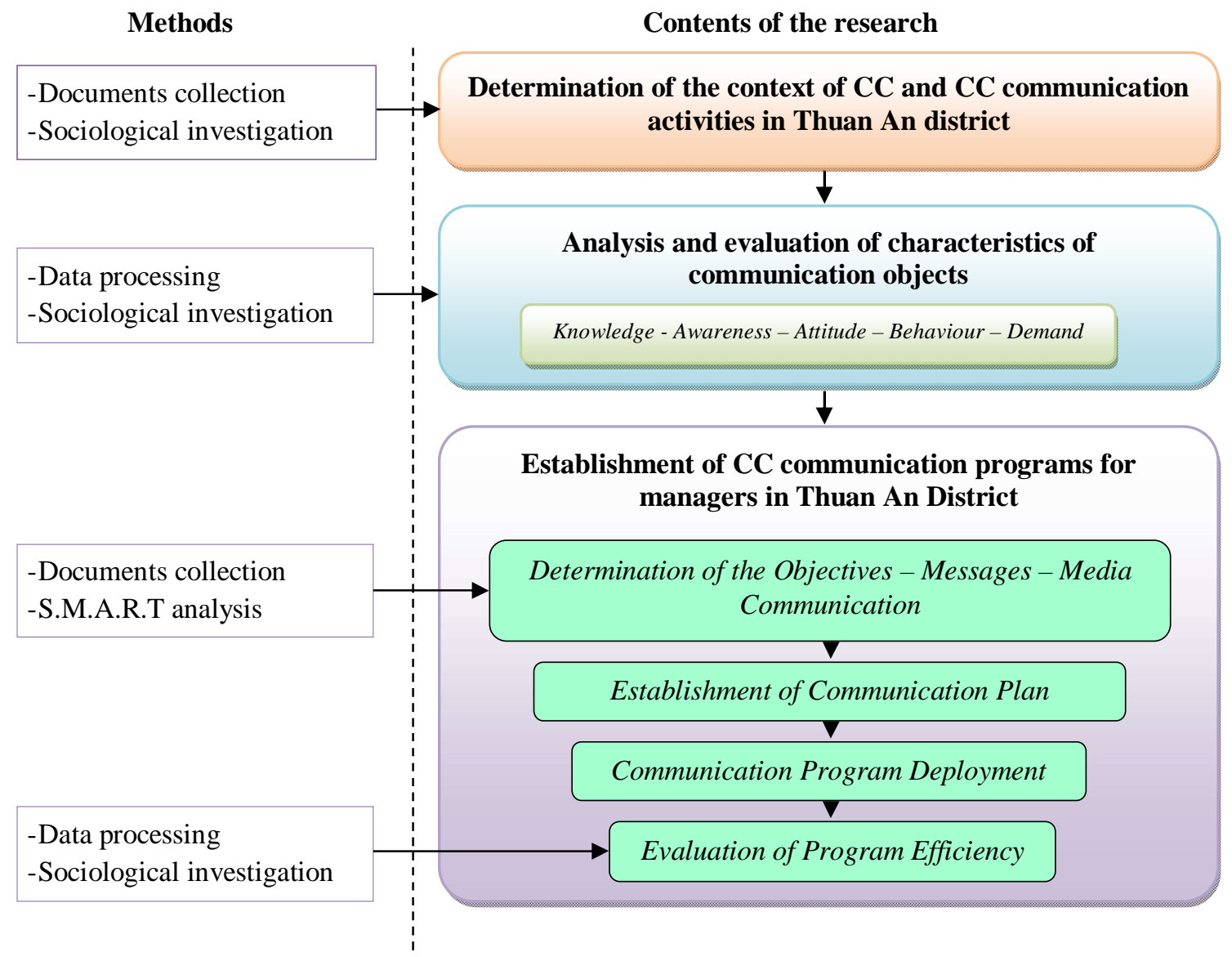

Figure 1. Research-oriented framework

Based on basic priciples of establishing a communication program in general and $\mathrm{CC}$ communication program in particular [11-12], combining experiences of other communication programs, a research-oriented framework is described in Figure 1.

\section{Method of document collection:} Documents/ data of $\mathrm{CC}$, disasters, CC communication programs in Thuan An District [13-18], as well as international and national studies and scientific reports relating to $\mathrm{CC}$ and $\mathrm{CC}$ communications $[1-5,7,11,12,19,20]$ were collected, providing the basis for designing and establishing $\mathrm{CC}$ communication programs for managers in Thuan An District. 
Method of sociological investigation: According to Truong [11], objectives of communication programs are expected to be increased in the following orders: awareness establishment, increase in concern, positive change in attitude and behavior, and then good habit forming. Characteristics of managers were therefore surveyed and evaluated as an important foundation for establishing suitable and effective $\mathrm{CC}$ communication programs. Thereby, current conditions of $\mathrm{CC}$, characteristics of managers (Knowledge - Awareness - Attitude - Behaviour - Demand) $[3,7,11]$, as well as the efficiency of $\mathrm{CC}$ communication sessions which were held in Thuan An district were investigated via questionnaires. There are 80 questionnaires that have been delivered and collected, including 40 questionnaires for managers of sectors of the district (10 units) and the rest for managers of wards/communes (09 wards and 01 commune).

Data processing method: investigation results were processed by MS Excel to evaluate managers' characteristics. Regarding CC awareness and attitude, investigation results were normalized and arranged in 3 levels. Awareness: Misunderstand/ Relatively understand/ Understand. Attitude: Not positive/ Relatively positivel Positive.

S.M.A.R.T (Specific, Measurable, Achievable, Realistic, Timely) analysis Method: was used to analyze and to select objectives of $\mathrm{CC}$ communication programs.

\section{RESULTS AND DISCUSSION}

\section{CC context and CC communication programs in Thuan An district}

Temperature in Thuan An has increased $\left(0,43-0,45^{\circ} \mathrm{C}\right)$; precipitation has decreased in volume $(400 \mathrm{~mm}-460 \mathrm{~mm})$ but increased in intensity $[9,13,17,18]$. In recent years, the number of tides has increased with tide/water levels exceeding an alarming level 3 from 0.11 to $0.18 \mathrm{~m}$. Inundation has widespreaded (mainly in urban land). Natural disasters and extreme weather events have increased in both frequency and intensity.

The Binh Duong CC scenarios indicate significantly increasing trends of future impacts related to rising temperatures; hurricane, tornado; rain, tides, etc. bringing about flood; salinisation; the risk of drought and water shortage, etc [9], negatively impacting on local daily life, production and community health. The reports on the disaster situation in Thuan An District (20082014) show that every year there is always damage of people and property; therefore, the total cost of restoring the damage is from hundreds million to billions Vietnam dong [13, $17,18]$.

The obtained information and documents from concerned bodies in Binh Duong Province combining with the results of investigation and survey show that currently there is no specific communication program of CC implemented in the province. $\mathrm{CC}$ issue is only briefly mentioned in the communication program regarding environment in general, which is likely to generate the gaps of information or misunderstanding about CC, thereby affecting attitude and behaviour of the objects.

\section{Trang 20}




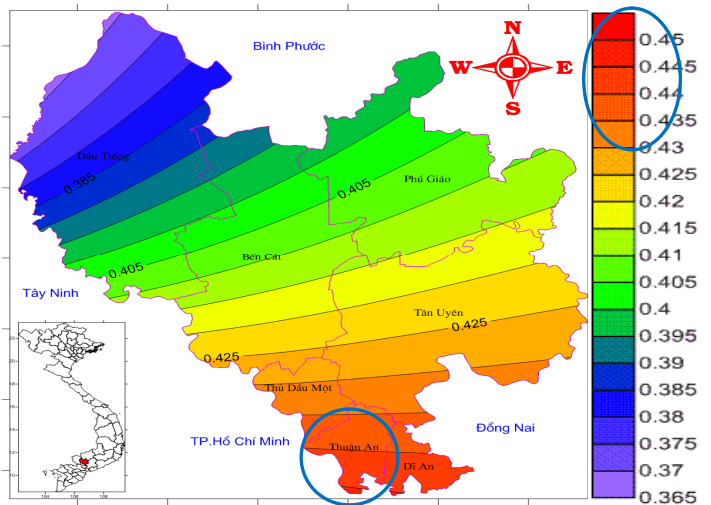

Figure 2: Distribution of the temperature differences in Binh Duong in 2009 as compared to 1999 [9]

\section{Evaluation of managers' characteristics regarding $\mathrm{CC}$.}

\section{Awareness}

The survey results were plotted in Figure 4. Details are as below:

- A few managers understand main manifestations and causes of CC $(<10 \%)$, while the proportion of managers who do not undertand is quite significant $(>40 \%)$.

- There is no manager well understanding greenhouse effect (GE) including the relationship between GE and CC, greenhouse gases, sources, and especially mechanisim/nature of GE.

- Concerning measures of coping to $\mathrm{CC}$ : No

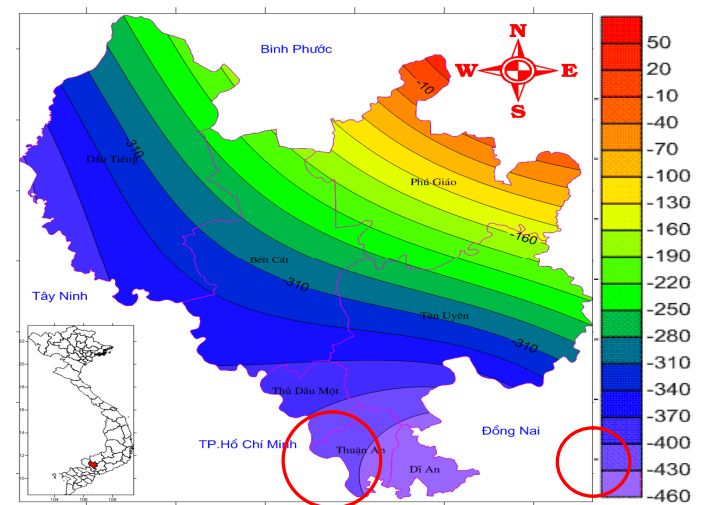

Figure 3: Distribution of the precipitation differences in Binh Duong in 2009 as compared to 1999 [9] manager can distinguish properly between mitigation and adaptation measures. A few managers know measures of coping to $\mathrm{CC}$ which the province has been implementing.

- Some investigated managers mistake between environmental protection activities and coping to $\mathrm{CC}$.

To sum up, the comprehension level about $\mathrm{CC}$ of managers is comparatively vague, i.e. they do not understand the nature and are still confused in distingusing related aspects. It could be explained by the significant lack of information relating to basic knowledge about $\mathrm{GE}, \mathrm{CC}$, and coping measures. 


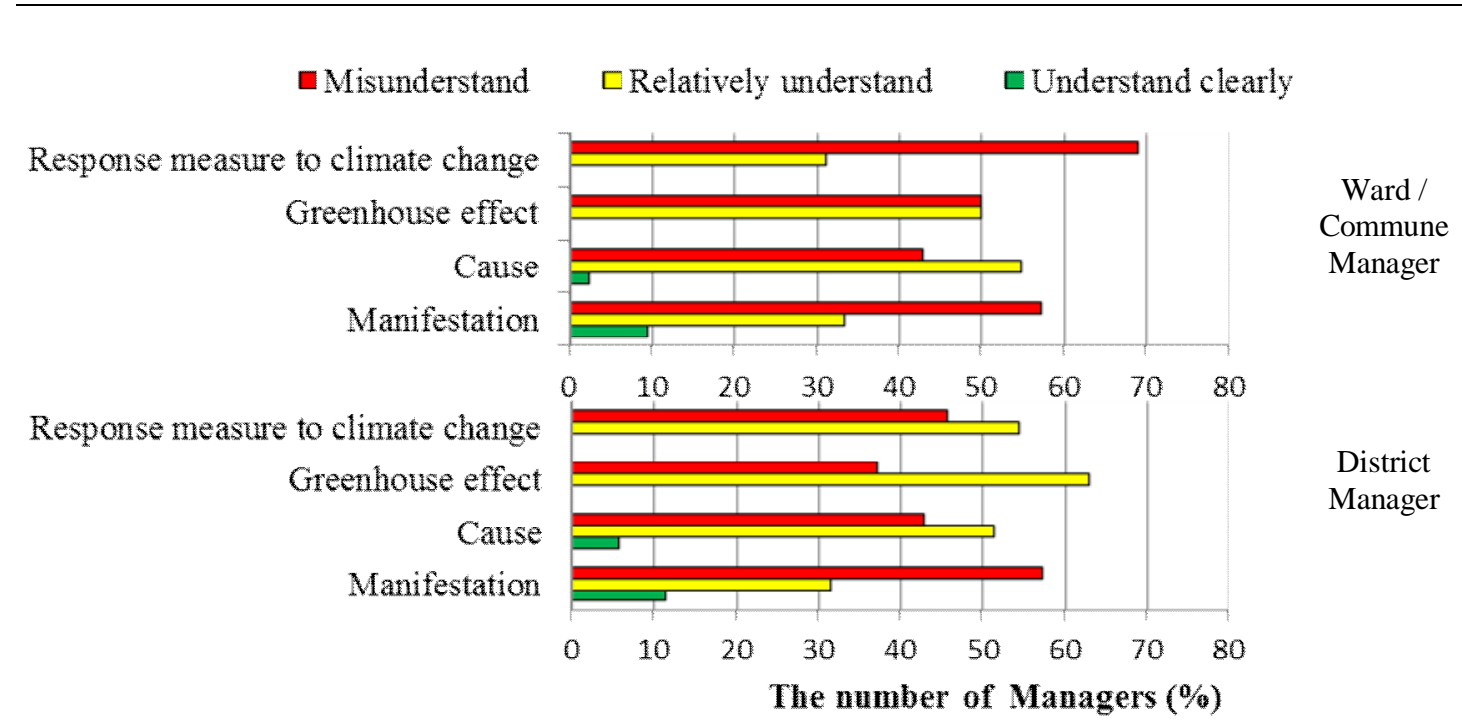

Figure 4: Managers' awareness of CC in Thuan An Ddstrict.

\section{Attitude}

The attitude of managers were evaluated based on 03 aspects: personal viewpoint (Agree) Disagree) to judgements relating to $\mathrm{CC}$; attitude when participating in activities of coping to $\mathrm{CC}$, disaster prevention, water and electricity saving in the role of managers, etc.; the expectation to be trained about $\mathrm{CC}$, disasters, and coping measures, ect. Accordingly, more than $90 \%$ of managers were evaluated to have relatively positive or positive attitude to the $\mathrm{CC}$ issue.

\section{Behaviour}

Managers' behaviour to $\mathrm{CC}$ issue is basically expressed via completed tasks in coping to $\mathrm{CC}$ and disasters, as well as measures for water and electricity saving with the role of anagers. The survey results showed that most of managers have positive actions. The fact that comparatively vague knowledge of $\mathrm{CC}$ of managers but relatively positive / positive behaviors could be resulted from their related knowledge, their positive habits, or/and their accountability in work, etc.

In general, differences in awareness, attitude, and behaviour to $\mathrm{CC}$ issue of district managers and ward/commune managers were not significant; therefore, it is possible to establish the same communication materials for these two objetcs.

\section{Demand for CC communication}

Communication demand was reviewed on the following aspects: media/channels, subjects, time, and the personal role when joining the $\mathrm{CC}$ communication programs.

- Communication media: Basing on following criteria such as understandable, attractive, flexible of time, suitable, etc., the survey results showed Television, Internet, Training, Newspaper/ Magazine to be chosen with a high rate (Figure 5), followed by the Speaker/ Radio, Arts, Poster, Brochure/ Manual, Competition.

- Communication subjects/topics: 02 preferred topics were (i) Basic knowledge of CC impacts and solutions and (ii) Basic knowledge of $G E$. This also corresponds to mentioned information gaps.

- Communication time: More than $90 \%$ of managers expect to be trained about $\mathrm{CC}$ as soon as possible: on weekend (Saturday is preferred) for ward managers and on weekdays for district managers (Friday is preferred).

\section{Trang 22}


- Personal role: Most managers only expect to participate in $\mathrm{CC}$ communication programs with the role of information recipients, then they will communicate to their families, friends, neighbors. They do not want to be a communicators as a result of limited professional knowledge, communication skills, and personal conditions, etc.
Establishment of $\mathrm{CC}$ communication programs for Managers in Thuan An district

$\mathrm{CC}$ communication programs for managers in Thuan An district were established by the determination of objectives, messages, and communication channels.

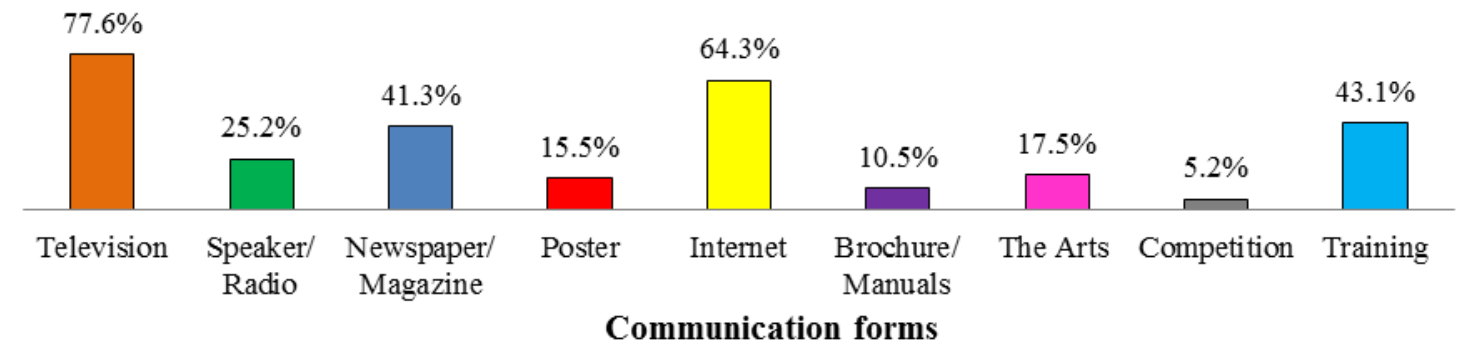

Figure 5: The survey results of Managers' priority for the communication channels

\section{Determination of objectives}

Based on the 05 basic objectives of a communication program as mentioned [11], characteristics of objects as investigated, the present objectives of $\mathrm{CC}$ communication programs for managers in Thuan An district include awareness establishment and increase in concern to CC.

\section{Selection of communication channels}

Television, Internet, Newspaper, Magazine are popular and attractive communication channels quickly updating the information of $\mathrm{CC}$. However, facility conditions, dependence, especially financial resources are barriers for this communication program. For Radio, the efficiency is not expected because people's radio listening habits have gradually changed as well as this media is no longer as popular as before. For Arts, the amount of communicating information is relatively little; moreover, personnel and financial resources are obstacles for this program.

Meanwhile, Training characteristics are direct interaction and diverse, systematic, and indepth information; Manual/ Training books with much information transmission, flexible access time; Poster with the advantage of attracting a great concern from communities. These are considered appropriate channels and corresponding to the capacity of the program.

Based on the analysis of strengths and weaknesses of the media, expectations of managers, inheriting the experience of related communication programs as well as resources of this program, Training - Communication Document - Manual - Poster were chosen and prioritized as the main communication channels of the program.

\section{Establishment of communication messages}

On the basis of information gaps and $\mathrm{CC}$ communication demand, the role of managers in coping to $\mathrm{CC}$ as well as experiences from other CC communication programs, [7, 11], 04 main communication topics were selected for this program as follows: (1) The basic knowledge of $C C$; (2) Measures of coping to CC and natural disasters; (3) Integrating CC issue into development plans; (4) CC communications.

\section{Establishment of Communication Plan}


The CC communication sessions for managers in Thuan An district were proposed to be held on Friday (for District maganers) and Saturday (for Ward/ Commune managers).

Communication materials include:

- 01 material "Improvement of response capacity to $C C^{\circ}$ ' with 4 main contents corresponding to 4 communication topics: (1) What is CC? How has CC happened in Binh Duong province and Thuan An district?, (2)
Improvement of reponse capacity to $C C$ in Binh Duong province and Thuan An district., (3) Integrating CC issue into development plans, programs, and projects, (4) Establishment of CC communication strategy (Figure 6).

- 01 manual "CC and disaster - The coping measures (Figure 7).

- 02 Posters: "CC - The issue of concern in Binh Duong province" and "Changing awareness, actions to cope with climate change" (Figure 8).

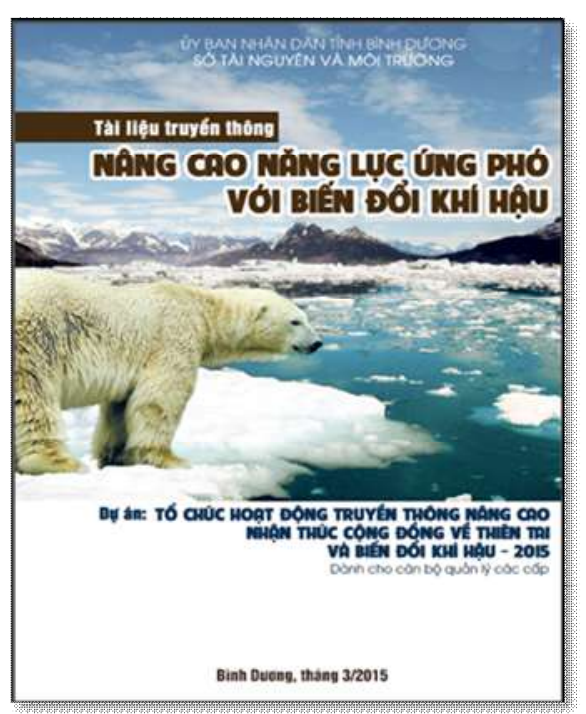

Figure 6: CC Communication Document

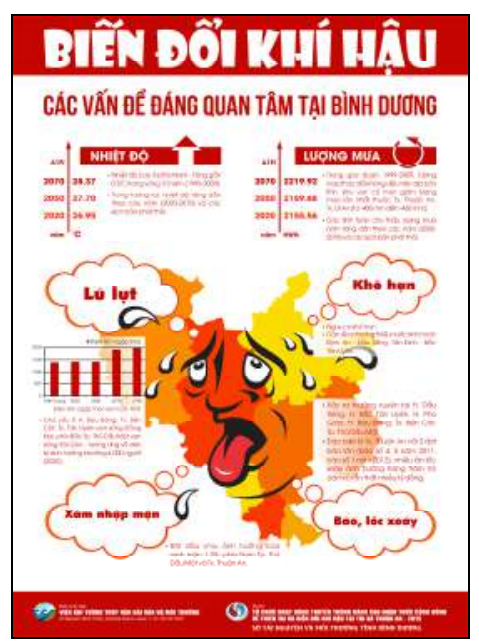

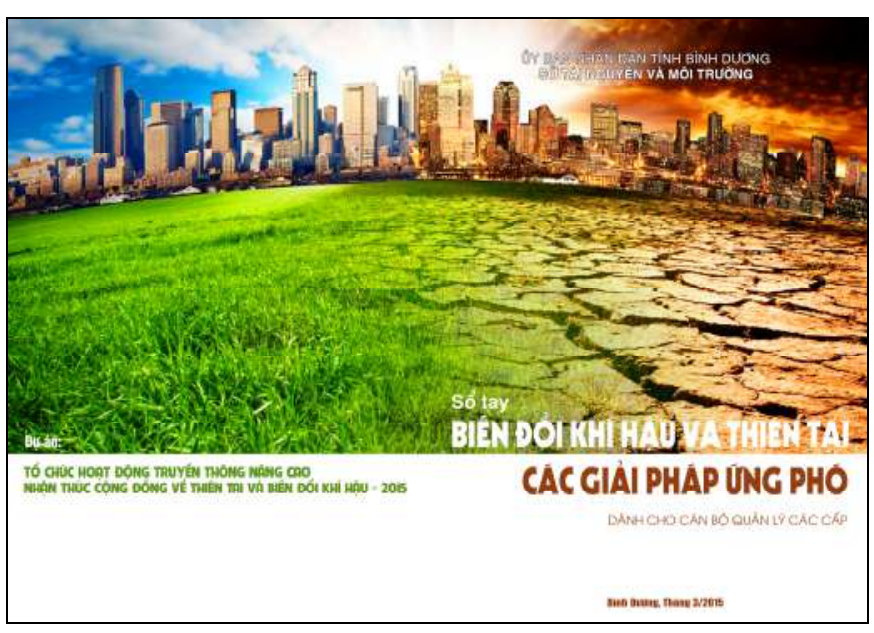

Figure 7: CC Communication Manual

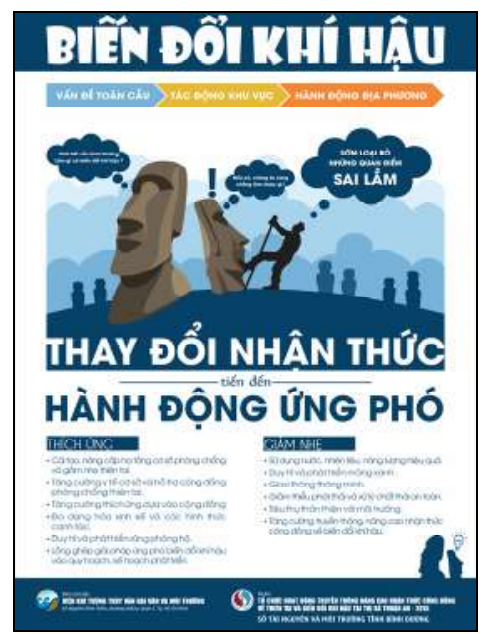

Figure 8: CC Communication Posters 
Accordingly, CC communication program for managers in Thuan An district was held on $18^{\text {th }}$ June for District managers and on $19^{\text {th }}$ June for Ward/Commune managers. The communication sessions were highly appreciated from managers: $100 \%$ of managers evaluated the $\mathrm{CC}$ communication program useful and beneficial, especially in the task of improving knowledge of $\mathrm{CC}, \mathrm{GE}$ as well as raising concern of managers on CC. Communication materials were evaluated to have clear layout, beautiful designs, necessary, and understandable delivered information. In addition, the communication method of communicators, hall decoration, games, etc. were the highlights of these communication sessions. With the limitations of time and resourses, there was no survey carried out after 6 month or a year since communication sessions, hence, it is lack of assessing change in managers' behaviors for $\mathrm{CC}$ issue. It could be implemented in the upcoming researches.

\section{CONCLUSIONS}

Based on the investigation, survey, and evaluation of communication and $\mathrm{CC}$ context, the characteristics of managers, principles and experiences in establishing communication programs, this work established CC communication program for managers in Thuan An district with appropriate objectives, topics, communication channels, and materials. Accordingly, the program was implemented practically and received positive feedback from the local managers. The research results could be applied and expanded to other districts in Binh Duong province in particular and other provinces in general, aiming to improve awareness, management capacity of local managers in order to be more proactive in response to $\mathrm{CC}$ and disasters. 
Nghiên cứu xây dựng chương trình truyền thông biến đổi khí hậu dành cho cán bộ quản lý các cấp - thí điểm tại thị xã Thuận An, tỉnh Bình Dương

\section{- Lê Ngọc Tuấn}

Trường Đại học Khoa học Tự nhiên, ĐHQG-HCM

- Điện Thị Thu Trang

Viện Khí tượng Thủy văn Hải văn và Môi trường

\section{TÓM TẮT}

Theo IPCC (2013), 95\% nguyên nhân gây biến đổi khi hậu (BĐKH) đến tù các hoạt động của con nguời, vì vậy, thay đổi tích cực nhận thức là vấn đề trọng tâm trong công tác ứng phó $B Đ K H$. Nghiên cứu này nhằm muc tiêu xây dưng các chuoong trình truyền thông về BĐKH dành cho cán bộ quản lý (CBQL) các cấp, thí điểm tại thị xã Thuận An (Bình Dương). Bối cảnh, đặc tính đối tương, lỗ hổng thông tin cũng nhu nhu cầu truyền thông được xác định thông qua việc điều tra, khảo sát, ... Trên cơ sở đó, chiến luợc truyền thông BĐKH được đề xuất, bao gồm: muc tiêu, thông diệp, phuơng tiện và các hoạt động truyền thông tuoong thích. Các tài liệu truyền thông (sổ tay, poster, tài liệu tập huấn...) cũng được xây dựng phù hợp. Mô hình này có thể mở rộng phạm vi áp dụng, góp phần nâng cao nhận thức, năng lực quản lý của cán bộ các cấp, tù đó chủ động hơn trong công tác ưng phó với tình hình BĐKH hiện nay trên địa bàn.

Tù khóa: biến đổi khi hậu, truyền thông, ưng phó biến đổi khí hậu

\section{REFERENCES}

[1]. World Bank, Climate Risks and Adaptation in Asian Coastal Megacities, (2010).

[2]. Intergovernmental Panel on Climate Change (IPCC), Climate Change 2013: The Physical Science Basis. Contribution of Working Group I to the Fifth Assessment Report of the Intergovemmental Panel on Climate Change, (2013).

[3]. The Vietnam Institute of Meteorology, Hydrology and Environment, Communication strategy on climate change.
Capacity Building for Climate Change Project, Hanoi, (2010).

[4]. UNEP, Raising awareness of climate change. United Nations Office at Nairobi/Pubishing Services Section/Nairobi, Kenya, (2006).

[5]. United Nations, United Nations Framework Convention On Climate Change, (1992).

[6]. People's Committee of Ho Chi Minh City, Plan "Raising awareness of community and disaster risk management based on 
community" of Ho Chi Minh City in 2013, (2012).

[7]. Van Khoa Le and Thi Kim Lien Tran, Studing and proposing activities to raise community awareness on climate change in Ho Chi Minh City, (2012).

[8]. Ministry of Natural Resources and Enviroment, National target program of response to climate change. Hà Nội, (2008).

[9]. Department of Natural Resources and Environment of Binh Duong Province, "Climate change response actions of Binh Duong Province for periods: 2013-2015, 2016 - 2020, 2021 - 2030" planning, (2012).

[10].People's Committee of Thuan An District, "Action program to actively respond to climate change, strengthen resource management capacity and protect environment in Thuan An District”, (2013).

[11].Quang Hoc Truong, Van Trieu Vu, Van Cuong Nguyen, Van Giai Phong Tran, Quang Tan Nguyen, Minh Thu Pham, Ngoc Huy Nguyen, Phong Tran and Thi Bich Ngoc Pham, Training of Trainers on climate change. Science and Technology, Ho Chi Minh City, (2011).

[12].Phong Tran, The Thuong Vu and Thi Bich Ngoc Vu, Climate change Communication for Community, Center for sustainable rural development (SRD), (2011).

[13].People's Committee of Binh Duong Province, The report "Summary of flood, storm control and rescue and taskoriented”, (2008, 2009, 2010, 2011, 2012, 2013).
[14].People's Committee of Binh Duong Province, "Organizing activities to commemorate - World Environment Day 5/6” planning, (2011, 2012, 2013, 2014, 2015).

[15].People's Committee of Binh Duong Province, "Organizing program to response National Week of clean water and sanitation" directive, (2015).

[16].Executive Committee of Youth Union of Binh Duong Province, "Organizing program to response Earth Hour" planning, (2014, 2015).

[17].People's Committee of Thuan An District, The report on the situation of disaster and repair work of Thuan An District period 2009 - 2012, (2013).

[18].People's Committee of Thuan An District, The report "Summary of flood, storm control and rescue and task-oriented", (2013, 2014).

[19].Quang Hoc Truong, Climate change and Biodiversity in relation to life and social development. Environmental Protection, (2007).

[20].Quang Hoc Truong, Duc Thi Pham and Thi Bich Ngoc Pham, Questions and answers on climate change. Center for sustainable rural development (SRD), (2011). 